\title{
Study of Energy Regulations in India
}

\author{
Aditee Potdar, Seema Unnikrishnan, and Anju Singh
}

\begin{abstract}
This paper reports the energy management systems in India, describing the command-and-control, market-based, and voluntary approaches. Energy-related command-and-control regulations focus majorly on the electricity sector. Renewable Energy Certificate is a market-based instrument for promoting renewable sources of energy and facilitating Renewable Purchase Obligation. An analysis of the accredited and registered projects under the scheme has been presented. The Perform-Achieve-Trade scheme targets eight sectors to promote energy-efficient technology and issues an energy saving certificate for every metric ton of oil equivalent of energy saved, which can be traded on special trading platforms. About $45 \%$ of the designated consumers have met their targets for 2014 - 15 while another $12.5 \%$ are on the verge of it. The voluntary regulations offer flexibility and are engaged with a broader community. They include diverse sectors such as households, Small and Medium Enterprises, and agriculture. The different energy regulation mechanisms have significantly contributed to energy-efficient technology, renewable energy, and a restructured electricity sector. The regulations employing different approaches have helped minimize the emissions of the energy sector, thereby contributing towards climate change mitigation.
\end{abstract}

Index Terms - Command-and-control, market-based mechanism, renewable energy certificate mechanism, perform-achieve-trade scheme, voluntary approach.

\section{INTRODUCTION}

With an increase in global population, our energy needs are also rising. The current pace of India's economic growth, together with government programs, suggests a robust growth in future power demand [1], which will create a necessity to increase energy production from conventional and non-conventional sources. Industrial energy use is responsible for a major share of anthropogenic greenhouse gas (GHG) emissions and, thus, more efficient industrial energy management and use can significantly contribute to mitigating climate change [2]. Energy efficiency is commonly seen as the most economical, minimally polluting, and most readily-available energy saving option existing in the industrial sector worldwide, which can contribute to development goals related to reducing poverty and to the global sustainability goals related to reducing emissions [3]. Emerging economies like India must meet their increasing energy demand and ensure reduction of the trade-off between economic growth and environmental degradation [2].

India, in its submission of Intended Nationally Determined Contribution to the United Nations Framework Convention

Manuscript received October 31, 2015; revised January 28, 2016.

The authors are with the National Institute of Industrial Engineering (NITIE), Mumbai, Maharashtra 400087, India (e-mail: aditip17@ gmail.com, seemaunnikrishnan@gmail.com, dranjusingh@gmail.com). on Climate Change has committed towards reducing its emissions intensity of its Gross Domestic Product (GDP) by $33-35 \%$ of 2005 levels by 2030 [4]. This is to be achieved through increasing fuel efficiency standards, adopting building energy codes, augmenting forest cover, and making greater use of renewable energy sources. In this context, it is imperative that a robust analysis of the current Indian situation, as majorly applicable to its industrial sector, is conducted to ascertain how close we are to becoming a low carbon economy. In this paper, we attempt to analyze India's energy regulation mechanisms and ascertain the most effective approach.

\section{ENERGY REGULATIONS IN INDIA}

The Energy Conservation Act, 2001 provides a legal directive for the implementation of energy efficiency measures through the Bureau of Energy Efficiency (BEE) and designated agencies in each state. Several schemes and programs have been initiated under the National Mission for Enhanced Energy Efficiency (NMEEE) present under the National Action Plan on Climate Change (NAPCC), and are covered under distinct categories - direct regulation (command-and-control), market-based instruments (economic instruments), and soft instruments (voluntary approaches) as proposed by [5].

\section{A. Command-and-Control (CAC)}

The term 'command-and-control' regulation implies a certain form of regulation that specifies a precise compliance method rather than simply an emission level [6]. Certain studies indicated direct regulation improving environmental performance [7], [8] while others compared and contrasted the effectiveness of the mandatory approach to incentivizing environmental adjustments made by companies (e.g. [9], [10]).

Table I presents an overview of the energy-related CAC regulations in India.

\section{B. Market-Based Instruments (MBIs)}

MBIs are regulations that influence environment-friendly actions through market signals rather than specific directives regarding pollution control levels or methods [11]. The performance of MBIs for environmental protection provides valuable evidence that MBIs can achieve major cost savings while accomplishing their environmental objectives [12], [13]. The performance of these systems offers lessons about the importance of flexibility, simplicity, the role of monitoring and enforcement, and the capabilities of the private sector to make markets of this kind work [11].

Several economic and other instruments are under discussion to contribute to energy-saving and climate protection objectives nationally and internationally, and 
among them are different forms of tradable certificates. Tradable green certificates for renewable energy and tradable white certificates as a market-based tool to foster energy efficiency are in effect in the European Union [14]. Similarly, in India, Renewable Energy Certificate (REC) mechanism and Perform-Achieve-Trade (PAT) scheme are currently being implemented as MBIs for trading in renewable energy and energy efficiency, respectively.

TABLE I: OVERVIEW OF ENERGY-RELATED CAC REGULATIONS IN INDIA

\begin{tabular}{|c|c|c|}
\hline REGULATION & $\begin{array}{l}\text { YEAR OF } \\
\text { ENTRY } \\
\text { INTO } \\
\text { FORCE }\end{array}$ & $\begin{array}{l}\text { MINISTRY/ AGENCIES } \\
\text { INVOLVED }\end{array}$ \\
\hline $\begin{array}{c}\text { Energy } \\
\text { Conservation Act }\end{array}$ & 2001 & $\begin{array}{l}\text { Ministry of Power (MoP), } \\
\text { Central Government, State } \\
\text { Government, BEE }\end{array}$ \\
\hline Electricity Act & 2003 & $\begin{array}{c}\text { MoP, Central Government, State } \\
\text { Government, Central Electricity } \\
\text { Authority (CEA), Central } \\
\text { Electricity Regulatory } \\
\text { Commission (CERC), State } \\
\text { Electricity Regulatory } \\
\text { Commission (SERC) }\end{array}$ \\
\hline $\begin{array}{l}\text { National Electricity } \\
\text { Policy }\end{array}$ & 2005 & $\begin{array}{c}\text { MoP, Central Government, State } \\
\text { Government, CEA, CERC, } \\
\text { SERC }\end{array}$ \\
\hline $\begin{array}{l}\text { Integrated Energy } \\
\text { Policy }\end{array}$ & 2006 & $\begin{array}{c}\text { Planning Commission of India, } \\
\text { CERC, SERC }\end{array}$ \\
\hline Tariff Policy & 2006 & $\begin{array}{c}\text { MoP, Central Government, State } \\
\text { Government, CEA, CERC, } \\
\text { SERC }\end{array}$ \\
\hline Hydro Power Policy & 2008 & $\begin{array}{l}\text { MoP, CEA, Ministry of Water } \\
\text { Resources, Central Water } \\
\text { Commission, Ministry of New } \\
\text { and Renewable Energy } \\
\end{array}$ \\
\hline $\begin{array}{l}\text { National Action } \\
\text { Plan for Climate } \\
\text { Change }\end{array}$ & 2008 & $\begin{array}{l}\text { Prime Minister's Office on } \\
\text { Climate Change, Nodal } \\
\text { Ministries for each mission and } \\
\text { related Ministries, Ministry of } \\
\text { Finance, Planning Commission }\end{array}$ \\
\hline $\begin{array}{l}\text { National Policy on } \\
\text { Biofuels }\end{array}$ & 2009 & $\begin{array}{c}\text { National Biofuel Steering } \\
\text { Committee, Department of } \\
\text { Biotechnology, } \\
\text { Bureau of Indian Standards, } \\
\text { Planning Commission, Ministry } \\
\text { of New and Renewable Energy, } \\
\text { Ministry of Environment, Forests } \\
\text { and Climate Change, Ministry of } \\
\text { Petroleum \& Natural Gas, } \\
\text { Ministry of Rural Development, } \\
\text { Ministry of Agriculture, Ministry } \\
\text { of Panchayati Raj, Ministry of } \\
\text { Science and Technology, } \\
\text { Ministry of Finance, Ministry of } \\
\text { Road, Transport and Highway, } \\
\text { Ministry of Railways, State } \\
\text { Governments }\end{array}$ \\
\hline $\begin{array}{l}\text { National Electricity } \\
\text { Plan }\end{array}$ & 2012 & $\begin{array}{c}\text { CEA, Central Government, State } \\
\text { Government }\end{array}$ \\
\hline
\end{tabular}

\section{1) Renewable energy certificate mechanism}

The Electricity Act, 2003 mandated Renewable Purchase Obligation (RPO) targets for electricity distribution companies to purchase a certain percentage of their total power requirement from renewable energy (RE) sources. RPO is a compulsion on the SERC to procure a certain percentage of the total power purchased during a financial year from RE sources [15]. In 2008, India's NAPCC set a target called the Renewable Purchase Obligation to produce $15 \%$ of the country's electricity with RE sources by 2020. Further, under the Jawaharlal Nehru National Solar Mission, the Indian government aims to develop 20,000 megawatt (MW) of solar energy by 2022 [16]. This target has been revised to $100,000 \mathrm{MW}$ by 2022 [17]. To help reach these targets in a cost-effective manner, India initiated a market-based mechanism called Renewable Energy Certificates [16]. Since RE sources are not uniformly distributed throughout the country, REC was introduced to help the obligated entities to meet their RPO compliance under the Electricity Act, 2003, irrespective of the availability of local RE sources, and create a national-level market to encourage the RE generation and capacity addition [18].

An analysis of the REC market indicated the signing of 2638 renewable energy generators till February 2015. The RECs issued until February 2015 are 21,399,881 while the RECs redeemed through Power Exchanges are 8,692,161. A trend of the number of RECs issued and RECs redeemed from March 2011 to February 2015 is presented in Fig. 1. The data of REC issuance and redemption can be procured from the REC Registry of India website. The REC projects are implemented in the sectors of wind, solar thermal, solar PV, small hydro, geothermal, biomass, urban or municipal waste, biofuel cogeneration, and others.

1110 projects with a total capacity of $4991.79 \mathrm{MW}$ have been proposed by accredited RE Generators till February 2015. The state of Maharashtra leads in the number of accredited projects (411), followed by 265 projects from Tamil Nadu, 2 projects each from Kerala and Delhi and 1 project each from Nagaland, Telangana and Tripura. In terms of capacity, the accredited projects in Tamil Nadu reported the highest capacity of $1219.57 \mathrm{MW}$, followed by a capacity of $1002.01 \mathrm{MW}$ in Maharashtra. Tripura and Telangana reported the least capacity of $4.98 \mathrm{MW}$ and $2 \mathrm{MW}$, respectively.

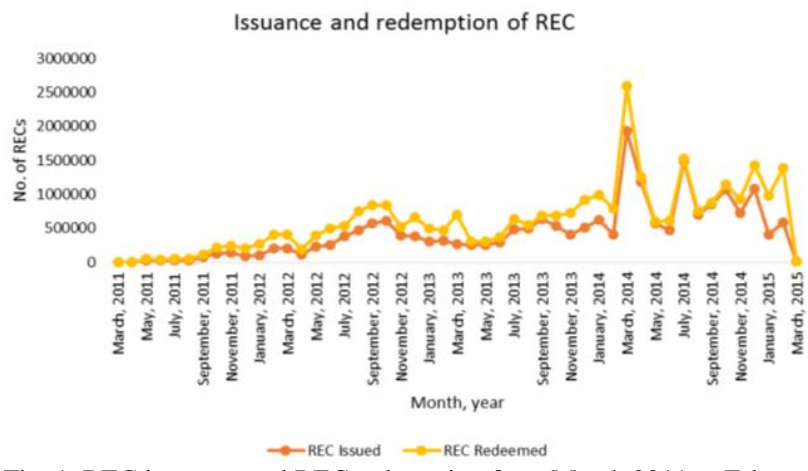

Fig. 1. REC issuance and REC redemption from March 2011 to February 2015

Fig. 2 depicts the state-wise distribution of units according to different sources of accredited REC projects. A majority of the projects are reported in the wind sector. Maharashtra leads in wind projects, followed by Tamil Nadu. Solar PV projects were mainly reported in Rajasthan, Madhya Pradesh, Maharashtra, Tamil Nadu, and Andhra Pradesh. Projects in Small Hydro were reported majorly in Himachal Pradesh, Maharashtra, and Jammu and Kashmir. Tamil Nadu and Maharashtra reported biomass projects also, in addition to solar and wind projects; Uttar Pradesh also reported several 
biomass-based projects. Several biofuel cogeneration projects were reported in Uttar Pradesh and Maharashtra.

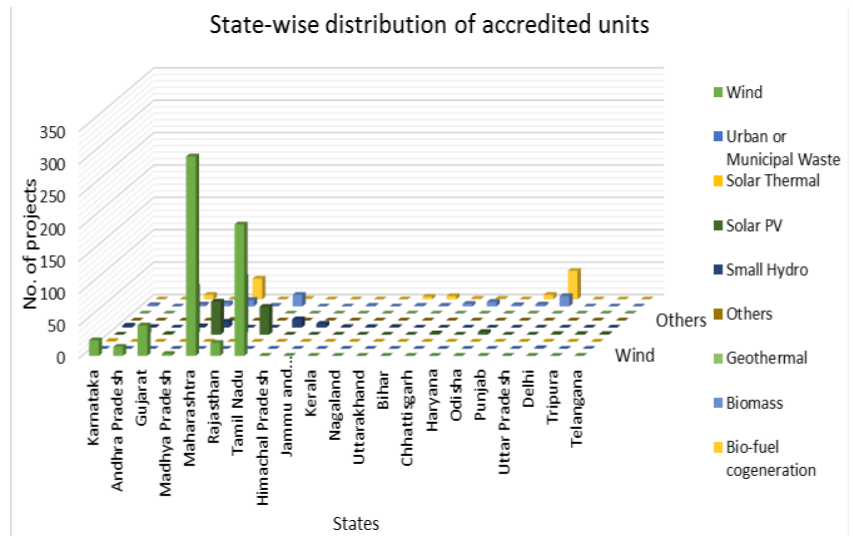

Fig. 2. State-wise distribution of accredited units.

The capacity of accredited projects from different sources in each state is presented in Fig. 3. Though Tamil Nadu reported fewer projects in the wind sector than Maharashtra, it reported the highest capacity of 948.95MW. Rajasthan and Madhya Pradesh reported a capacity of $212.22 \mathrm{MW}$ and 132.41MW of Solar PV projects, respectively. The highest capacity of 126.01MW of Small Hydro project was reported from Himachal Pradesh. Uttar Pradesh was the frontrunner in Biomass (216.6MW) as well as Biofuel cogeneration projects (513.53MW).

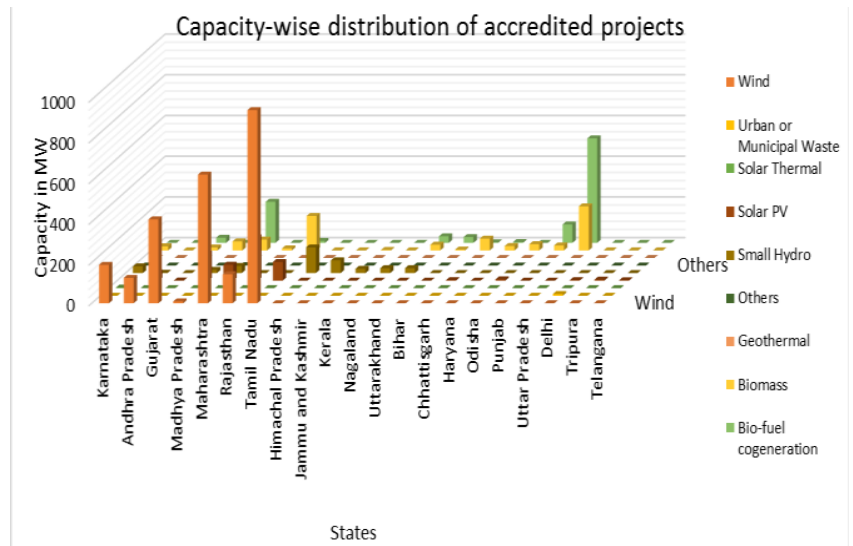

Fig. 3. Capacity-wise distribution of accredited projects.

1060 projects with a capacity of $4739.92 \mathrm{MW}$ have been proposed by the registered RE Generators as of February 2015, with Maharashtra topping this list, reporting 400 units of 1039.86MW capacity. Following Maharashtra was Tamil Nadu with 261 units of 1193.12MW. 2 projects were reported from Kerala having a capacity of $23.2 \mathrm{MW}$. Only 1 project each by registered RE Generators was reported in Nagaland and Delhi with capacities of 24MW and 2.14MW, respectively.

Fig. 4 presents state-wise distribution of registered projects. In the wind sector, Maharashtra reported the highest number of projects (300) followed by Tamil Nadu (202). Rajasthan and Madhya Pradesh reported the highest number of Solar PV projects, i.e., 88 and 74 , respectively. The maximum number of projects registered under Small Hydro was 12 from Himachal Pradesh. Significant number of Biomass-related registered projects was reported from Tamil Nadu (17) and Uttar Pradesh (16). The maximum registered Biofuel cogeneration projects were from Uttar Pradesh (44), followed by Maharashtra (33).

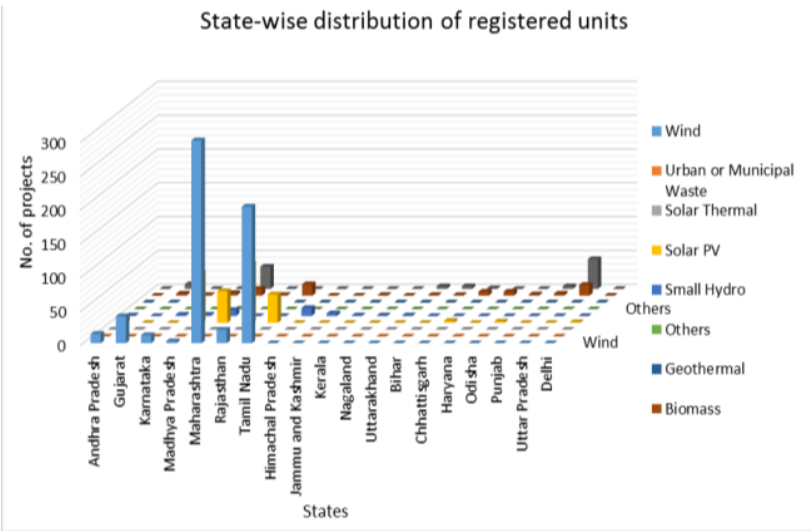

Fig. 4. State-wise distribution of registered units.

The capacity-wise distribution of registered projects has been highlighted in Fig. 5. Tamil Nadu, Maharashtra, and Gujarat have high capacity and potential for wind sector projects. Together, these three states have a potential of 1919.08MW from wind projects. Rajasthan has the highest capacity of $211.22 \mathrm{MW}$ in Solar PV projects, followed by Madhya Pradesh with $132.41 \mathrm{MW}$ capacity. Maximum capacity of 117.01MW of Small Hydro projects was reported from Himachal Pradesh. Uttar Pradesh leads in Biomass (216.6MW) and Biofuel cogeneration (513.53MW) registered projects. Following Uttar Pradesh was Tamil Nadu in Biomass projects with a capacity of $167.6 \mathrm{MW}$. Maharashtra followed Uttar Pradesh in Biofuel cogeneration projects with $247.85 \mathrm{MW}$ capacity.

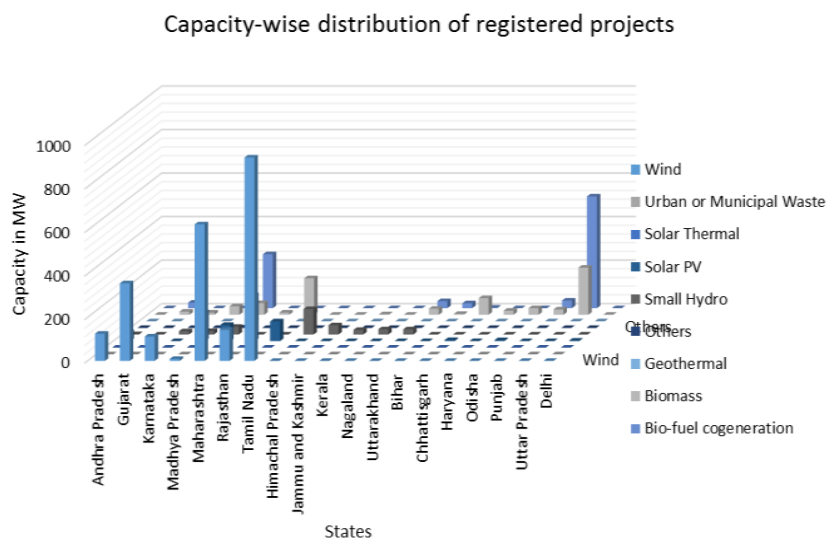

Fig. 5. Capacity-wise distribution of registered projects.

\section{2) Perform-achieve-trade scheme}

Perform-Achieve-Trade Scheme, a result of the NMEEE, is an ambitious project of the Government of India given its scale, complexities, timelines, and absence of precedence [19]. The MoP is the nodal ministry for NMEEE and implements the PAT program through the BEE. The PAT program aims to promote energy-efficient technology [15]. PAT is a market-based mechanism to enhance cost effectiveness of improvements in energy efficiency and facilities through certification of energy savings that can be traded. Genesis of the PAT mechanism flows out of the provision of the Energy Conservation Act, 2001 [19]. Through the PAT scheme, India has become the first developing country to adopt an energy-efficiency trading 
scheme that uses market-based mechanisms [20]. The scheme was projected to reduce India's $\mathrm{CO}_{2}$ emissions by around $23 \mathrm{~m}$ tonnes of $\mathrm{CO}_{2}$ equivalent by 2014 , helping to meet half of the 2020 emissions reduction signed up at Copenhagen [21].

The MoP has notified industrial units and other establishments consuming energy more than a threshold as Designated Consumers (DCs) under the Energy Conservation Act, 2001 [15]. Out of the 15 DCs, eight (Aluminum, Cement, Chlor-Alkali, Pulp \& Paper, Fertilizers, Power Generation Plants, Steel, and Textiles) are covered under the PAT Scheme [19]. These eight sectors were chosen as per the energy consumption cut-off decided by BEE. The PAT scheme sets plant-specific targets instead of a sector-specific target with the average reduction target being $4.05 \%$ [20].

On completion of the monitoring and verification process by BEE, the PAT registry issues the energy saving certificates (ESCert), equivalent to metric ton of oil equivalent (mtoe) of energy saved for that time period [15]. The DCs are issued with ESCert if they meet or exceed the specific energy consumption (SEC) target as mentioned in the scheme while if they fail, they must purchase the ESCerts [22].

Plants that are unable to meet their target (either through their own actions, or through purchase of certificates, or both) are subject to financial penalties equal in cost to the energy shortfall in meeting the SEC reduction target, in addition to a fixed penalty of INR 1 million and purchase of ESCerts [22]. Thereafter, ESCerts are issued and can be traded between entities. The value of each mtoe consumed for the purpose was fixed at INR 10154/- for the year 2011-12 [23]. The BEE has set up registry and exchanges for the trading of ESCert (special trading platforms created in the two power exchanges - Indian Energy Exchange and Power Exchange India Limited) and maintenance of records for its creation, trading, and cancellation to enable its cross-sectoral use and synergy with RECs [24].

The first cycle of the PAT mechanism is running over 2012-2015 for eight sectors covering 478 DCs [23]. The review of the scheme is done annually based on the Energy Auditor's report, with the ESCert being issued annually since April 2013 [15]. After the end of PAT Cycle I (2012-15), which occurred in March 2015, an accredited energy auditor will verify the annual SEC for 2014-15 of each DC. The ESCerts will be issued to plants based on their verified performance, and is traded between August and November 2015, after which the plants will be assessed for compliance [22]. Fig. 6 highlights the National Energy Saving targets under PAT. Out of the total energy saving targets of 6.6 million mtoe, $80 \%$ lies in three industries, viz., Thermal Power Plants, Iron and Steel, and Cement, with targets of 3.211 mtoe, 1.486 mtoe, and 0.816 mtoe, respectively [25].

An update by the BEE on the PAT scheme highlighted the annual (unverified) reporting by the DCs at the end of 2013 14 (Fig. 7). It specified the compliance of the DCs with the PAT scheme. While 217 plants had already met their 2014-15 targets, 60 were close to completion [22].

After the completion of the first PAT cycle in 2014-15, and the assessment of the performance of the DCs the targets for the second PAT cycle will be established [22]. The second phase of the PAT scheme will bring under its ambit three more heavily polluting industries - railways, oil refineries and power distributors. It will also include more units of the existing sectors [26].

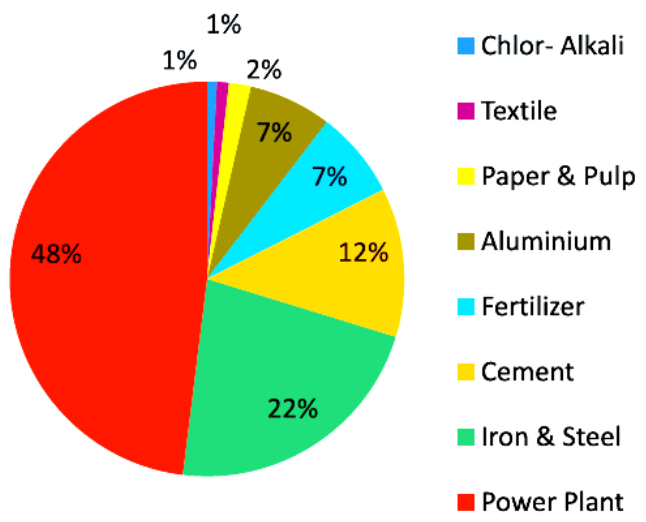

Fig. 6. National energy saving targets under PAT (Source: BEE, 2012)

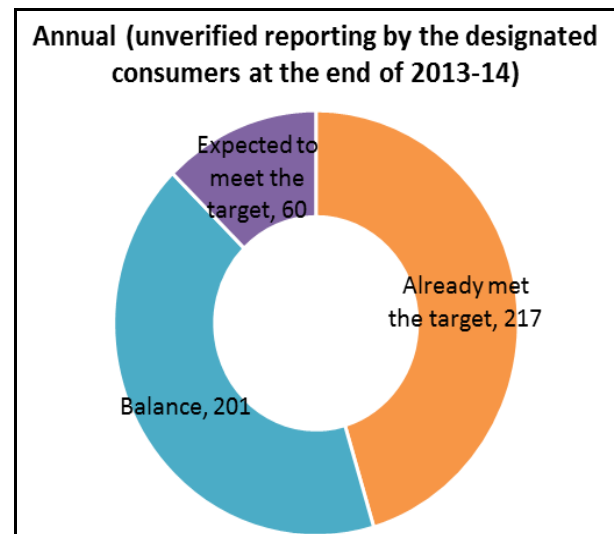

Fig. 7. Annual unverified reporting by the designated consumers at the end of 2013-14.

\section{Voluntary Approaches}

Voluntary activities have played a central role as an effective measure to encourage industries to take socially responsible actions [27]. Flexible and inexpensive management of environmental problems makes voluntary agreements popular [28]. Voluntary programs offer a new architecture that emphasizes performance-based systems (that specify desired outcomes) rather than technology-based standards (that prescribe methods of compliance) while more effectively engaging the broader community [29]. When participating in voluntary activities, industries have full control of their responses to unexpected contingencies, which allows them to aim for ambitious goals without being unduly concerned about future uncertainty [27]. On the other hand, voluntary approaches are criticized because they are not legally mandatory. In addition, the targets set are often not very ambitious, in fact sometimes closer to "business as usual" [28].

Since the 1990s, developing countries have strengthened and amended the voluntary agreements to enhance their industrial energy efficiency [30]. In recent years, voluntary agreements have been adopted in some industrialized countries as an important policy instrument for energy saving [31]. Providing support and incentives to implement energy conservation measures, and explicitly enhancing energy-efficient management practices are also significant [32]. The voluntary programs in India related to energy are reported in Table II. 
TABLE II: VOLUNTARY PROGRAMS RELATED TO ENERGY IN INDIA

\begin{tabular}{|c|c|c|}
\hline PROGRAM & $\begin{array}{c}\text { YEAR OF } \\
\text { ESTABLISHMENT }\end{array}$ & $\begin{array}{c}\text { AGENCY/ } \\
\text { MINISTRIES } \\
\text { INVOLVED }\end{array}$ \\
\hline $\begin{array}{l}\text { Indian Green } \\
\text { Building Council } \\
\text { (IGBC) }\end{array}$ & 2001 & $\begin{array}{l}\text { Confederation of Indian } \\
\text { Industry (CII) }\end{array}$ \\
\hline $\begin{array}{l}\text { National Energy } \\
\text { Labeling Program }\end{array}$ & 2006 & $\begin{array}{l}\text { BEE, Manufacturers' } \\
\text { Associations of } \\
\text { Industries, Bureau of } \\
\text { Indian Standards, } \\
\text { Consumer } \\
\text { Organizations }\end{array}$ \\
\hline $\begin{array}{l}\text { Memorandum of } \\
\text { Understanding } \\
\text { (MoU) between } \\
\text { the Members of the } \\
\text { India-Brazil- } \\
\text { South Africa } \\
\text { Dialogue Forum } \\
\text { on establishing a } \\
\text { trilateral task team } \\
\text { on biofuels }\end{array}$ & 2006 & $\begin{array}{c}\text { Ministry of } \\
\text { Non-Conventional } \\
\text { Energy Sources, MoP, } \\
\text { Ministry of Petroleum \& } \\
\text { Natural Gas, Ministry of } \\
\text { Agriculture, Ministry of } \\
\text { Rural Development and } \\
\text { Ministry of Science and } \\
\text { Technology }\end{array}$ \\
\hline $\begin{array}{c}\text { Energy } \\
\text { Conservation } \\
\text { Building Code } \\
\text { (ECBC) }\end{array}$ & 2007 & BEE, MoP \\
\hline $\begin{array}{l}\text { MoU among the } \\
\text { Government of the } \\
\text { Republic of South } \\
\text { Africa, the } \\
\text { Government of the } \\
\text { Republic of India } \\
\text { and the } \\
\text { Government of the } \\
\text { Federative } \\
\text { Republic of Brazil } \\
\text { on Cooperation in } \\
\text { Wind Resources }\end{array}$ & 2007 & $\begin{array}{c}\text { Ministry of } \\
\text { Non-Conventional } \\
\text { Energy Sources, MoP, } \\
\text { Ministry of Petroleum \& } \\
\text { Natural Gas, Ministry of } \\
\text { Agriculture, Ministry of } \\
\text { Rural Development and } \\
\text { Ministry of Science and } \\
\text { Technology }\end{array}$ \\
\hline $\begin{array}{l}\text { Bachat Lamp } \\
\text { Yojana }\end{array}$ & 2009 & $\begin{array}{c}\text { BEE, Electricity } \\
\text { Distribution Companies, } \\
\text { Households }\end{array}$ \\
\hline $\begin{array}{c}\text { BEE Small and } \\
\text { Medium } \\
\text { Enterprises (SME) } \\
\text { Program }\end{array}$ & 2009 & BEE \\
\hline $\begin{array}{l}\text { BEE Agriculture } \\
\text { Demand Side } \\
\text { Management } \\
\text { Program }\end{array}$ & 2009 & $\begin{array}{l}\text { State Governments, } \\
\text { MoP, BEE, Ministry of } \\
\text { Water Resources, } \\
\text { Electricity Distribution } \\
\text { Companies, Electricity } \\
\text { Service Companies }\end{array}$ \\
\hline $\begin{array}{l}\text { MoU among the } \\
\text { Government of the } \\
\text { Republic of South } \\
\text { Africa, the } \\
\text { Government of the } \\
\text { Federative } \\
\text { Republic of Brazil } \\
\text { and the } \\
\text { Government of the } \\
\text { Republic of India } \\
\text { on Cooperation in } \\
\text { the Area of Solar } \\
\text { Energy }\end{array}$ & 2010 & $\begin{array}{c}\text { Ministry of } \\
\text { Non-Conventional } \\
\text { Energy Sources, MoP, } \\
\text { Ministry of Petroleum \& } \\
\text { Natural Gas, Ministry of } \\
\text { Agriculture, Ministry of } \\
\text { Rural Development and } \\
\text { Ministry of Science and } \\
\text { Technology }\end{array}$ \\
\hline
\end{tabular}

\section{RESULTS AND DISCUSSION}

The global burden of GHG emission and climate change cannot be tackled unless a concerted effort is undertaken towards carbon neutrality. However, this is a challenge in energy-intensive developing countries where the trade-off between industrialization and environmental conservation can become monumental. To meet these challenges, a different perspective of energy production and consumption is essential. Regulation is one such perspective. Since the introduction of the Energy Conservation Act, 2001 and the Electricity Act, 2003, the energy sector in India has experienced a drastic change. Many new CAC, MBI, and voluntary regulations related to energy have been introduced to fulfill the obligations set under different regulations. Setting up of the BEE to handle programs related to energy efficiency marked a significant development in the energy sector of India.

India being a developing economy relies majorly on CAC mechanisms. With the introduction and success of MBIs in developed countries, India is learning to develop and implement such mechanisms successfully. A range of voluntary programs has also been implemented along with CAC and MBI.

Focusing on the energy sector, India has a considerable number of CAC regulations majorly highlighting the electricity sector, which is one of the greatest contributors to anthropogenic climate change. The Electricity Act, 2003 and its amendment, National Electricity Policy, 2005 and the Tariff Policy, 2006 promote competition in the electricity market apart from enhancing efficiency in operations and improvement in quality of supply of electricity in the country. The CAC regulations also emphasize electricity generation through RE and its use in transport as a fuel. Electricity generation through $\mathrm{RE}$ is being strongly promoted and incentives such as tax waivers, generation-based incentive, accelerated depreciation, etc. are granted.

The REC scheme as a market-based mechanism was well-received by the RE generators and accomplished the objective of meeting the RPO targets in selected states. Seven states viz., Meghalaya, Tamil Nadu, Nagaland, Uttarakh and, Himachal Pradesh, Rajasthan, and Karnataka have made laudable efforts to boost RE uptake in their energy mix and have achieved their RPO targets since 2009. Gujarat, Mizoram, and Chattisgarh have missed their targets by only a few percentage points while Jammu and Kashmir, Jharkhand, Manipur, Goa and Tripura are yet to open their RPO compliance account [33]. An analysis of the projects registered for REC mechanism shows a significant difference in the number of projects registered in each state. Restructuring or modification in the REC framework can be thought of, as the mechanism is skewed towards some states. Restructuring or modification will help the states with smaller RPO targets to tap their RE resources efficiently and utilize their RE capacity to the fullest. The Government of India is planning to introduce stricter penalties for failing to meet the RPO targets. There is a need for handholding of states that are yet to start or are near-zero or have just started with the RPO compliance. Lowering the price of RECs is an option, which is being implemented since January 2015. The policy and regulatory frameworks for RE development and different approaches to implement them have mostly been successful in Sri Lanka. This example of a fellow third world nation provides useful lessons for India to make the utmost use of its RE resources and the policy and regulatory frameworks that govern them [34]. 
An analysis of the accredited and registered projects shows that the wind sector in Maharashtra and Tamil Nadu is leading in terms of number as well as capacity. This can be attributed to the amenable local conditions in these areas. The Ministry of New and Renewable Energy released the Draft National Offshore Wind Energy Policy in 2013. This policy gives further impetus to developing offshore wind energy projects in Kerala, Karnataka, Goa, Tamil Nadu, and Gujarat. The Solar PV projects are highest in Rajasthan due to the availability of vast open spaces where solar panels can be set up. Himachal Pradesh reports maximum Small Hydro projects due to its strategic geographical location. Uttar Pradesh leads in Biomass and Biofuel Cogeneration projects due to its position in the agriculture-intensive Gangetic plains where the agro-waste can be used for generating electricity. There is scope for generating electricity through urban or municipal waste. However, there is a need to develop appropriate technology for Indian waste, which is majorly wet. Electricity generation through geothermal projects is possible in certain areas of the country. The Ministry of New and Renewable Energy already released a draft National Policy on Geo-Thermal Energy. The technicalities need to be further worked out before tapping this potential resource.

The PAT scheme for energy efficiency is a one-of-its-kind market-based mechanism established in India. The scheme has received good response and support from the industry and reinstated the stringent monitoring and verification framework. To make the scheme robust, more DCs present under the Energy Conservation Act, 2001 should be included. The objective of China's Top-1000 Energy Consuming Enterprises program is similar to that of the PAT scheme. The Top-1000 program sets energy reduction targets for 1000 highest energy consuming enterprises. This program was one of the vehicles for achieving the ambitious goal set under the $11^{\text {th }}$ Five Year Plan of China for reducing energy consumption per unit of GDP by $20 \%$ between 2005 and 2010 [3]. In order to fulfill the $20 \%$ energy intensity reduction target, the Shanghai government had subsidized amounts of energy using entities for their energy conservation and efficiency improvement efforts. For such entities that have made great progress with energy consumption reduction, the Shanghai government offers some favorable conditions in allowance allocation in the pilot carbon emissions trading scheme [35]. Such measures may be introduced in India if the government plans to bring out a carbon emissions trading scheme in the future.

Voluntary regulations have been implemented in tandem with CAC and MBI mechanisms as they promote socially responsible behavior of firms. The energy-related voluntary regulations cover different sectors like households, SMEs, agriculture, etc. The building energy regulation can help overcome some of the significant market barriers and ensure that cost-effective energy efficiency opportunities are incorporated into new buildings. This is especially important in developing countries where several new buildings are coming up and the energy prices and market often do not encourage the use of efficient technologies. They also serve by increasing the accountability of the average citizen towards energy conservation and clean development. However, the implementation and application of energy regulations for conservation of energy in buildings are still far behind in developing countries as compared to developed countries [36]. A worthy example can be that of United Kingdom, which is aspiring to reduce carbon emissions in the building sector, aiming to achieve nearly zero carbon buildings by 2020 [37]. These buildings work by controlling carbon emissions from all possible sources and through regulated energy use. In India, schemes like ECBC should be promoted largely. The United States Green Building Council's Leadership in Energy \& Environment Design certification or CII's IGBC certification or The Energy and Resources Institute's Green Buildings Rating System India certification should be made mandatory for private and government institutions that consume a significant amount of energy. Apart from the Tier-I cities where green buildings are made compulsory, there are several upcoming Tier-II and Tier-III cities that consume a tremendous amount of energy and where green buildings should be made mandatory.

Mass media should play a strong role in promoting the National Energy Labeling Scheme at the grass root levels. The BEE should increase the products under mandatory labeling category after a particular period and more products should be introduced under voluntary labeling category. Also, the payback period for such labeled products can be reduced further by introducing more energy-efficient technologies. An innovative approach applied in Japan for enhancing energy efficiency in home appliances was that of an eco-label in addition to the governmental regulation [38]. India can also adopt a similar approach providing a boost to the Ecomark Scheme of India, 1991.

The BEE SME program is a novel plan to bring about energy efficiency in SMEs where the small clusters contribute to high energy consumption. The program should be extended to more such clusters after the assessment of the initially selected 21 clusters. The subsidy available to Micro, Small, and Medium Enterprises (MSMEs) from the Ministry of MSME for technology up-gradation should be promoted considerably.

The Bachat Lamp Yojana of BEE has been doing satisfactorily and has registered several Clean Development Mechanism projects. The project can be promoted better, resulting in reduced GHG emissions. The diversification across sectors will help reduce the energy-related emissions, thereby mitigating climate change.

It is amply clear from the above discourse that a single approach towards energy management is incapable of answering all the situations. MBIs may need to be preceded and supplemented by CAC actions [39]. Any market-based or conventional policy instrument cannot be appropriate for all environmental problems, with the best choice depending upon the characteristics of the specific environmental problem, and the social, political, and economic context [11].

All the efforts undertaken to minimize energy usage, enhance energy efficiency, and promote the use of clean energy will contribute towards reducing the emissions intensity of India's GDP by 33 to 35 percent by 2030 from 2005 level as proposed in the Intended Nationally Determined Contributions (INDC) submitted to the United Nations Framework Convention on Climate Change. According to the Paris Agreement, each country has to strengthen its INDCs 
every 5 years [40]. To achieve the current INDCs and undertake stricter INDCs in the future, a single regulatory approach will not suffice. Though there are several energy regulations, proper implementation is the key to gain the desired benefits. India needs to progress beyond its current measures for energy to reduce the GHG emissions, thereby contributing to climate change mitigation.

\section{CONCLUSION}

A wide range of command-and-control, market-based and voluntary regulations related to energy are present in India. The CAC regulations need to be implemented stringently as the recent change in the energy-related regulations offers several opportunities to benefit every stakeholder. With the Government of India rolling out market-based schemes such as REC and PAT, the dream of making India a 'low carbon economy' will come true in the years to come. The voluntary regulations need to be publicized so that firms can implement them and control their energy-related matters better. The energy regulation mechanism that can work best in the Indian context is a combination of all three approaches. The suggested combination will work best here as being a developing economy, India needs command-and-control regulations to set a limit on the emissions; it also requires market-based mechanisms to develop a strong market for profit earning from energy-related activities and voluntary standards to independently regulate the same.

\section{REFERENCES}

[1] R. Harmsen, L. Moth, and A. Kumar, "Applicability of energy saving obligations to Indian electricity efficiency efforts," Energy Strateg. Rev., vol. 2, pp. 298-306, 2014.

[2] United Nations Industrial Development Organization (UNIDO). (2009). Energy and climate change. greening the industrial agenda. [Online]. Available: http://www.unido.org/fileadmin/user_media/Services/Energy_and_Cl imate_Change/Office_of_the_Director/UNIDO $\% 20$ ECC\%20Branch $\% 20$ Brochure.pdf

[3] L. K. Price and A. T. McKane. (2008). Policies and measures to realise industrial energy efficiency and mitigate climate change. UN-Energy Energy Efficiency Cluster. [Online]. Available: http://www.unido.org/fileadmin/user_media/Services/Energy_and_Cl imate_Change/EPU/UN\%20Energy\%202009\%20Policies\%20and\%2 0Measures\%20to\%20realise\%20Industrial\%20Energy\%20Efficiency $\% 20$ and $\% 20$ mitigate $\% 20$ Climate $\% 20$ Change_small.pdf

[4] United Nations Framework Convention on Climate Change (UNFCCC). (2015). India's Intended Nationally Determined Contribution.: Working towards Climate Justice. [Online]. Available: http://www4.unfccc.int/submissions/INDC/Published\%20Documents /India/1/INDIA\%20INDC\%20TO\%20UNFCCC.pdf

[5] J. A. Bŕio, E. Ferández, and B. Junquera, "The role of the public administrations in the promotion of the environmental activity in Spanish industrial companies," Ecol. Econ., vol. 40, no. 2, pp. 279-294, 2002.

[6] D. M. Driesen. (1998). Is emissions trading an economic incentive program?: Replacing the command and control/economic incentive dichotomy. Wash. Lee Law Rev. [Online]. 55(2). pp. 289-350. Available: http://scholarlycommons.law.wlu.edu/wlulr/vol55/iss2/2

[7] K. Silvo, M. Melanen, A. Honkasalo, S. Ruonala, and M. Lindström, "Integrated pollution prevention and control - The Finnish approach," Resour. Conserv. Recycl., vol. 35, no. 1-2, pp. 45-60, 2002.

[8] F. Testa, D. Styles, and F. Iraldo, "Integration of findings from two separate studies that suggest direct regulation is an efficient approach to industrial environmental improvement," J. Clean. Prod., vol. 21, pp. $1-10,2012$.
[9] B. Clemens and T. J. Douglas, "Does coercion drive firms to adopt "voluntary" green initiatives? Relationships among coercion, superior firm resources, and voluntary green initiatives," J. Bus. Res., vol. 59, pp. 483-491, 2006.

[10] M. Potoski and A. Prakash, "The regulation dilemma and US environmental governance," Public Adm. Rev., vol. 64, pp. 137-148, 2004.

[11] R. N. Stavins. (2001). Experience with market-based environmental policy instruments. resources for the future. [Online]. Available: http://www.rff.org/documents/rff-dp-01-58.pdf

[12] R. Kemp, "Technology and environmental policy: Innovation effects of past policies and suggestions for improvement," Organization for Economic Co-operation and Development (OECD) Proceedings Innovation and the Environment, OECD, pp. 35-61, 2000.

[13] J. Klok, A. Larsen, A. Dahl, and K. Hansen, "Ecological tax reform in Denmark: History and social acceptability," Energy Policy, vol. 34, no. 8, pp. 905-916, 2006.

[14] O. Langniss and B. Praetorius, "How much market do market-based instruments create? An analysis for the case of "white" certificates," Energy Policy, vol. 34, pp. 200-211, 2006.

[15] R. Kumar and A. Agarwala, "Renewable energy certificate and perform, achieve, trade mechanisms to enhance the energy security for India," Energy Policy, vol. 55, pp. 669-676, 2013.

[16] G. Shrimali, S. Tirumalachetty, and D. Nelson. (2012). Falling short: An evaluation of the Indian renewable certificate market. Climate Policy Initiative - Indian School of Business Report. [Online]. Available:

http://climatepolicyinitiative.org/wp-content/uploads/2012/12/Falling -Short-An-Evaluation-of-the-Indian-Renewable-Certificate-Market.pd $\mathrm{f}$

[17] Ministry of Finance (MoF). (2015). Budget Speech by Hon'ble Finance Minister. [Online]. Available: http://indiabudget.nic.in/bspeecha.asp

[18] R. M. Shereef and S. A. Khaparde, "Current status of REC mechanism in India and possible policy modifications to way forward," Energy Policy, vol. 61, pp. 1443-1451, 2013.

[19] S. Dube, R. Awasthi, and V. Dhariwal. (2011). Can the learning's from international examples make the 'perform achieve and trade (pat) scheme' perform better for India. Emergent Ventures India. [Online] Available:

http://www.scribd.com/doc/200742839/A-Discussion-Paper-on-India -s-Perform-Achieve-and-Trade-PAT-Scheme

[20] N. Singh. (2013). Creating market support for energy efficiency: India's perform, achieve and trade scheme. Inside Stories on Climate Compatible Development. Climate \& Development Knowledge Network. [Online]. Available: http://cdkn.org/wp-content/uploads/2013/01/India-PAT_InsideStory. pdf

[21] Economic Intelligence Unit (EIU), "PAT solution?" The Econ., vol. 18, no. 2, p. 1, 2011

[22] Bureau of Energy Efficiency (BEE). (2015). Perform, Achieve, and trade (PAT) programme. [Online]. Available: http://www.beeindia.in/SVR\%20Note\%20on\%20PAT\%20DG\%2024 $-11-14[1] . p d f$

[23] Bureau of Energy Efficiency (BEE). (2012). Perform, achieve and trade. power booklet released by ministry of power, government of India. [Online]. Available: http://beenet.gov.in:90/downloadbooks.aspx?fname=BEE_PAT_Boo klet_Final.pdf

[24] T. Bhattacharya and R. Kapoor, "Energy saving instrument — ESCerts in India," Renew. Sustain. Energy Rev., vol. 16, no. 2, pp. 1311-1316, 2012.

[25] Deloitte. (2013). Securing tomorrow's energy today: Policy \& Regulations. Market Transformation in Energy Efficiency. [Online]. Available:

http://www.deloitte.com/assets/Dcom-India/Local\%20Assets/Docume nts/IEC\%202013/Resource_allocation_and_pricing.pdf

[26] Sustainability Outlook. (2015). Top 5 sustainability watch-outs for $2015 . \quad$ [Online]. Available: http://sustainabilityoutlook.in/content/top-5-sustainability-watch-outs $-2015-511031$

[27] M. Wakabayashi, "Voluntary business activities to mitigate climate change: Case studies in Japan," Energy Policy, vol. 63, pp. 1086-1090, 2013.

[28] S.-F. Lo, "Global warming action of Taiwan's semiconductor/TFT-LCD industries: How does voluntary agreement work in the IT industry?” Technol. Soc., vol. 32, pp. 249-254, 2010.

[29] C. Sabel, A. Fung, and B. Karkkainen, "Beyond backyard environmentalism: How communities are quietly refashioning 
environmental regulations,” Boston Rev., vol. 24, no. 5, pp. 4-11, 1999.

[30] L. Bernstein, J. Roy, K.C. Delhotal, J. Harnisch, R. Matsuhashi, L. Price, K. Tanaka, E. Worrell, F. Yamba, and Z. Fengqi. (2007). Industry. In Climate Change 2007: Mitigation. Contribution of Working Group III to the Fourth Assessment Report of the Intergovernmental Panel on Climate Change. [Online]. Available: https://www.ipcc.ch/pdf/assessment-report/ar4/wg3/ar4-wg3-chapter7 .pdf

[31] Y. Hu, "Implementation of voluntary agreements for energy efficiency in China," Energy Policy, vol. 35, pp. 5541-5548, 2007.

[32] S. Krarup and S. Ramesohl, "Voluntary agreements on energy efficiency in industry - Not a golden key, but another contribution to improve climate policy mixes," J. Clean. Prod., vol. 10, pp. 109-120, 2002.

[33] A. Pratap, M. Ram, and A. P. Pathanjali. (2013). Powering ahead with renewables. Leaders \& Laggards. [Online]. Available: http://www.greenpeace.org/india/Global/india/report/2013/poweringahead-with-renewables.pdf

[34] P. D. C. Wijayatunga, "Regulation for renewable energy development: Lessons from Sri Lanka experience," Renew. Energy, vol. 61, pp. 29-32, 2014

[35] L. Wu, H. Qian, and J. Li, "Advancing the experiment to reality: Perspectives on Shanghai pilot carbon emissions trading scheme," Energy Policy, vol. 75, pp. 22-30, 2014.

[36] J. Iwaro and A. Mwasha, "A review of building energy regulation and policy for energy conservation in developing countries," Energy Policy, vol. 38, pp. 7744-7755, 2010.

[37] G. Zapata-Lancaster and C. Tweed, 'Designers' enactment of the policy intentions. An ethnographic study of the adoption of energy regulations in England and Wales," Energy Policy, vol. 72, pp. 129-139, 2014.

[38] T. Okubo, "Energy-saving regulations and commodity prices," Environ. Econ. Policy Stud., vol. 15, pp. 93-132, 2013.

[39] K. Ahmed. (2012). Getting to green: a sourcebook of pollution management policy tools for growth and competitiveness. Washington, DC: World Bank. [Online]. Available: http://documents.worldbank.org/curated/en/2012/01/16565836/gettin g-green-sourcebook-pollution-management-policy-tools-growth-comp etitiveness

[40] United Nations Framework Convention on Climate Change (UNFCCC). (2015). Adoption of the Paris Agreement. [Online]. Available: http://unfccc.int/resource/docs/2015/cop21/eng/109r01.pdf

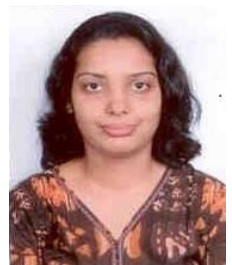

Aditee Potdar secured her masters' degree in environmental science from University of Mumbai, India. Aditee Potdar completed her post graduate diploma in environmental law from National Law School of India University, Bangalore, India. Aditee Potdar is currently pursuing her Ph.D at National Institute of Industrial Engineering (NITIE), Mumbai, India. Aditee Potdar's major field of study is environmental regulations and climate change.

Prior to joining Ph.D, she worked at the Centre for Environmental Studies at NITIE as a research associate. She also worked as an environmental analyst at an environmental consultancy and laboratory. She has about 7 publications in peer-reviewed journals till date.

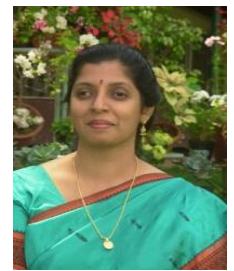

Seema Unnikrishnan received her Ph.D from Fellowship of National Institute of Industrial Engineering (NITIE), Mumbai in the area of hazardous waste management. Seema Unnikrishnan completed her post graduate diploma in environmental law from Madurai Kamaraj University, India.

She is currently working as a professor in NITIE, Mumbai. Before joining NITIE, she worked with the Central Pollution Control Board for three years. She has several research publications in the field of environmental management. Her areas of research interest are hazardous waste management, cleaner production, and disaster prevention and management.

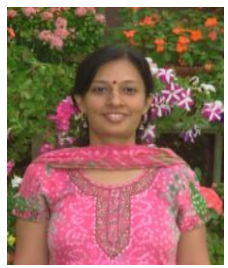

Anju Singh holds a Ph.D. from the Centre for Environmental Science and Engineering (CESE), Indian Institute of Technology (IIT) Bombay, Mumbai, India.

She is currently working as a faculty at National Institute of Industrial Engineering, Mumbai and is involved with teaching, training, and research in environment management. She worked in IIT Bombay as scientist and consultant and successfully executed international/national sponsored and consultancy projects at CESE and Regional Sophisticated Instrumentation Centre. She has more than 60 papers to her credit in journals and conferences. 